\title{
Efek Model Pembelajaran Kooperatif Tipe STAD dan Jigsaw Terhadap Penguasaan Konsep Fisika
}

\author{
Ni Nyoman Sri Putu Verawati ${ }^{1}$, Satutik Rahayu ${ }^{2}$, Nur Fadilah Aning Detri ${ }^{3}$ \\ 1,2,3 Program Studi Pendidikan Fisika, FKIP, Universitas Mataram \\ Email: fadilah.nfad@gmail.com
}

\begin{abstract}
Abstrak. Penelitian ini bertujuan untuk mengetahui efek model pembelajaran kooperatif tipe STAD dan Jigsaw terhadap penguasaan konsep fisika peserta didik kelas XI SMAN 1 Kediri. Jenis penelitian ini adalah quasi experiment dengan desain penelitian posttest only control group. Populasi penelitian ini adalah peserta didik kelas XI SMAN 1 Kediri tahun pelajaran 2018/2019 dengan teknik pengambilan cluster random sampling. Terdapat dua sampel yang diambil yaitu sampel sebagai kelas yang diberikan perlakuan model pembelajaran kooperatif tipe STAD (kelas eksperimen 1) dan kelas yang diberi perlakuan model pembelajaran kooperatif tipe Jigsaw (kelas eksperimen 2). Nilai rata-rata-rata tes akhir penguasaan konsep kelas eksperimen 1 dan 2 berturutturut adalah 73,69 dan 61,07. Kedua kelas homogen dan terdistribusi normal. Data penguasaan konsep dianalisis menggunakan uji-t polled varians. Hipotesis penelitian menunjukkan bahwa thitung lebih besar dari ttabel $(2,841>2,021)$ pada taraf signifikan $5 \%$ yang berarti bahwa $\mathrm{H}_{\mathrm{o}}$ ditolak dan $\mathrm{H}_{\mathrm{a}}$ diterima.Berdasarkan hasil analisis data dan pembahasan, dapat disimpulkanbahwa terdapat pengaruh antara penerapan model pembelajaran kooperatif tipe STAD dan Jigsaw terhadap penguasaan konsep fisika peserta didik kelas XI SMAN 1 Kediri.
\end{abstract}

Kata Kunci: Pembelajaran Kooperatif, STAD, Jigsaw, Penguasaan Konsep

\section{PENDAHULUAN}

Fisika merupakan salah satu bagian dalam ilmu sains yang pada umumnya terdiri dari sekumpulan pengetahuan, cara berpikir, dan proses penyelidikan (Larasati, 2014). Kumpulan pengetahuan tersebut dapat berupa fakta, konsep, prinsip, hukum, teori, dan model. Fisika dalam pembelajaran di sekolah mengacu pada kurikulum yang digunakan. Tujuan umum pembelajaran fisika menurut Kurikulum 2013 ialah menguasai konsep dan prinsip serta mempunyai keterampilan mengembangkan pengetahuan dan sikap percaya diri sebagai bekal untuk melanjutkan pendidikan pada jenjang yang lebih tinggi serta mengembangkan ilmu pengetahuan dan teknologi (Kemendikbud, 2014). Pembelajaran pada dasarnya merupakan suatu interaksi positif antara pendidik dan peserta didik dan antara peserta didik dengan peserta didik lainnya (Rahayu, 2015).Peran guru di dalam kelas seharusnya dapat membantu siswa menemukan fakta, konsep, atau prinsip bagi diri mereka sendiri, bukan mengendalikan seluruh kegiatan pembelajaran di dalam kelas agar pembelajaran fisika menjadi lebih bermutu dan bermakna. Hakim, dkk (2018), pelaksanaan pendidikan yang bermutu merupakan suatu upaya yang dapat dilakukan untuk menyiapkan sumber daya manusia yang berkualitas dalam menghadapi tantangan yang semakin kompleks

Pembelajaran fisika akan lebih bermakna jika siswa terlibat aktif dalam proses mengamati, memahami, dan menerapkan fakta, konsep, atau prinsip fisika dalam kehidupan sehari-hari. Berdasarkan hal tersebut di perlukan model pembelajaran yang sesuai agar siswa dapat terlibat aktif dalam proses pembelajaran fisika. Islamiah, dkk (2018), proses pembelajaran yang baik harus mampu memberikan kesempatan kepada peserta didik untuk berperan aktif dalam setiap pembelajaran yang dilakukan.Hikmawati (2014), tidaklah cukup bagi guru hanya menggantungkan diri pada satu pendekatan atau metode pembelajaran. Guru dengan bermodalkan kemampuan melaksanakan berbagai model pengajaran, dapat memilih model yang sesuai dengan lingkungan belajar atau sekelompok siswa tertentu.

Berdasarkan hasil observasi di SMAN 1 Kediri, di dalam proses pembelajaran peserta 
didik belum terlibat secara aktif. Peserta didik belum terbiasa dengan konsep-konsep fisika yang bersifat abstrak dan asing bagi peserta didik. Pembelajaran di dalam kelas juga dilakukan secara monoton, yang menyebabkan kurang bermaknanya pembelajaran fisika yang menyebabkan kejenuhan dan rendahnya hasil belajar peserta didik. Faktor rendahnya hasil belajar peserta didik juga dipengaruhi oleh rendahnya penguasaan konsep fisika dan kurangnya interaksi antar peserta didik sehingga diskusi terjadi secara tidak merata yang menyebabkan beberapa siswa menjadi pasif dan mengalami kebosanan selama pembelajaran fisika.

Konsep merupakan dasar bagi prosesproses mental yang lebih tinggi untuk merumuskan prinsip-prinsip dan generalisasigeneralisasi untuk memecahkan masalah, seorang siswa harus mengetahui aturan-aturan yang relevan, dan aturan-aturan ini didasarkan pada konsep-konsep yang diperolehnya, jadi penguasaan konsep merupakan syarat mutlak dalam mencapai keberhasilan pembelajaran fisika, karena merupakan suatu landasan dalam berpikir dan menumbuhkan kemampuan serta keterampilan dalam pembelajaran lainnya. Verawati, dkk (2017), penguasaan materi fisika menuntut kemampuan berpikir logis, kritis dan kreatif, sehingga penguasaan konsep fisika sudah harus matang agar dapat menumbuhkan proses berpikir yang lebih tinggi tersebut. Penguasaan konsep disini tidak hanya terbatas pada mengenal konsep, tetapi peserta didik harus dapat menghubungkan antara konsep yang satu dengan konsep lain yang masih ada kaitannya. Pembelajaran fisika tidak hanya sekedar menghafal, namun perlunya pemahaman yang lebih untuk meningkatkan kemampuan berpikir yang dimilikinya (Latifa, dkk, 2017).

Salah satu model pembelajaran yang dapat memenuhi kondisi tersebut adalah model pembelajaran kooperatif. Pada penelitian ini akan diterapkan model pembelajaran kooperatif, dimana menurut Buchari (2008), pembelajaran koperatif merupakan model pembelajaran dimana peserta didik belajar dalam kelompok kecil yang memiliki tingkat kemampuan yang berbeda. Setiap anggota saling bekerja samadengan membantu memahami suatu materi pembelajarannya. Menekankan pada kerjasama antarsiswa, ketergantungan, dan tanggung jawab dalam struktur, tugas, tujuan, dan hadiah.

Terdapat beberapa tipe dalam model pembelajaran kooperatif, namun yang digunakan pada penelitian ini adalah model pembelajaran kooperatif tipe STAD dan JIGSAW. Model pembelajaran kooperatif tipe STAD dan Jigsaw memiliki karakteristik yang tidak jauh berbeda. Perbedaan mendasar dari kedua teknik ini adalah pada model kooperatif tipe STAD didasarkan pada gagasan atau pemikiran bahwa peserta didik bekerja bersama-sama dalam belajar, dan bertanggung jawab terhadap penguasaan materi kelompok, sedangkan pada tipe Jigsaw, peserta didik dibebankan tanggung jawab secara individu untuk menguasi suatu bagian materi untuk diajarkan kepada anggota lainnya. Sehingga penguasaan materi kelompok merupakan tanggung jawab dari setiap peserta didik dalam kelompok tersebut. Penelitian ini bertujuan untuk mengetahui pengaruh model pembelajaran kooperatif tipe STAD dan Jigsaw terhadap penguasaan konsep fisika peserta didik kelas XI SMAN 1 Kediri.

\section{METODE PENELITIAN}

Penelitian ini dikategorikan sebagai penelitian eksperimen semu (quasi experiment) dengan desain posttest-only control group. Populasi penelitian ini adalah 3 kelas yang berisi 67 peserta didik SMA (Sekolah Menengah Atas). Sampel penelitian adalah 42 peserta didik yang terbagi dalam dua kelas yakni 21 peserta didik dalam kelas eksperimen 1 dan 21 peserta didik dalam kelas eksperimen 2. Pemilihan sampel dilakukan dengan metode "cluster random sampling". Peserta didik tersebut memiliki pengetahuan awal yang hampir sama yang diidentifikasi dari nilai mid semester gasal Tahun Ajaran 2018/2019. Pada kelas eksperimen 1 diberi perlakuan model pembelajaran kooperatif tipe STAD dan kelas eksperimen 2 diberi perlakuan model pembelajaran kooperatif tipe Jigsaw. Kedua kelas diberi pos-tes setalah perlakuan. 
Instrumen penelitian berupa tes kognitif uraian yang soalnya dikategorikan dalam 6 aspek kognitif berdasarkan taksonomi Bloom yang direvisi oleh Anderson dan Krathwohl (2015) yang sudah divalidasi dan diuji reliabilitasnya. Analisis data penguasaan konsep berupa uji homogenitas menggunakan uji-F dan uji normalitas menggunakan uji Chi Kuadrat, Kemudian dilanjutkan dengan uji hipotesis menggunakan uji-t polled varian dengan taraf signifikan 0,05.

\section{HASIL DAN PEMBAHASAN}

Uji coba instrumen yang diuji cobakan berupa tes penguasaan konsep berbentuk soal uraian sebanyak 10 soal. Instrumen tersebut telah diujikan kepada peserta didik kelas XII MS 1 SMAN 1 Kediri dengan jumlah peserta didik sebanyak 19 orang. Uji instrumen ini meliputi uji validitasdan reliabilitas. Seluruh soal didapatkan valid dan reliabel sehingga digunakan untuk mengambil data penguasaan konsep pada pos-tes. Data penguasaan konsep diambil setelah diberikan perlakuan berupa model pembelajaran kooperatif tipe STAD untuk kelas eksperimen 1 dan model pembelajaran kooperatif tipe Jigsaw untuk kelas eksperimen 2.

Tabel 1. Data Penguasaan Konsep

\begin{tabular}{|l|l|l|}
\hline \multicolumn{1}{|c|}{ Kelas } & Eksperimen 1 & Eksperimen 2 \\
\hline N & 21 & 21 \\
\hline Nilai Tertinggi & 95,00 & 47,50 \\
\hline Nilai Terendah & 87,50 & 30,00 \\
\hline Rata-rata & 73,69 & 61,07 \\
\hline SD & 15,26 & 14,19 \\
\hline
\end{tabular}

Berdasarkan data tersebut terlihat bahwa penguasaan konsep rata-rata kelas eksperimen 1 lebih besar daripada kelas eksperimen 2, adapun grafik penguasaan konsep tersebut ditunjukkan pada gambar 1 berikut ini

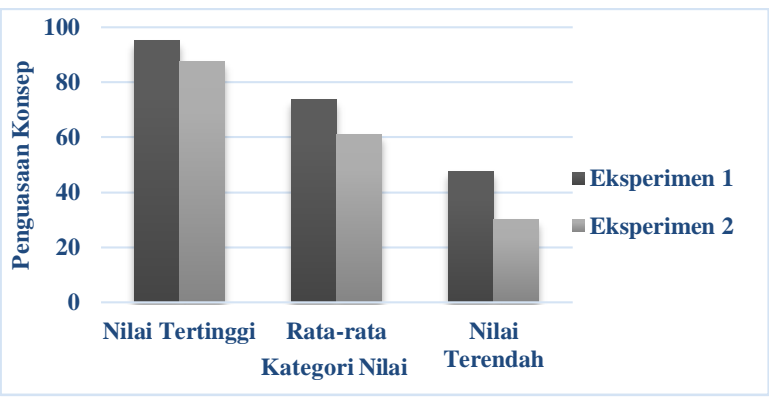

Gambar 1. Grafik Penguasaan Konsep
Pengujian data penguasaan konsep peserta didik diawali dengan uji homogenitas kedua data, yang dilanjutkan dengan uji normalitas, dan terakhir uji hipotesis menggunakan uji-t polled varians. Dari uji homogenitas data yang telah dilakukan didapat hasil $F_{\text {hitungsebesar }}$ 1,26 sedangkan $F_{\text {tabel }}$ sebesar 2,12 dengan taraf signifikan 0,05 . SehinggaF $F_{\text {hitung }}<F_{\text {tabel }}$ yang berarti data tes kedua kelas adalah homogen.

Selanjutnya dilakukan uji normalitas data tes akhir pada masing-masing kelas. Berdasarkan perhitungan yang telah dilakukan didapatkan nilai $\chi_{\text {hitung kelas }}^{2}$ eksperimen 1 dan kelas eksperimen 2 berturut-turut yaitu 7,20 dan 2,57, sedangkan nilai $\chi_{\text {tabel }}^{2}$ untuk kelas eksperimen 1 dan eksperimen 2 berturut-turut yaitu 9,48 dan 11,07, sehingga didapatkan bahwa kedua kelas memiliki $\chi^{2}{ }_{\text {hitung }}<\chi_{\text {tabel }}^{2}$ pada taraf signifikan $5 \%$, jadi kedua kelas terdistribusi normal.

Data tes akhir kedua kelas homogen dan terdistribusi normal. Untuk mengetahui apakah ada pengaruh model pembelajaran kooperatif tipe STAD dan Jigsaw terhadap penguasaan konsep dilanjutkan denga uji-t polled varians. Hasil uji statisti yang didapatkan menunjukkan nilai $t_{\text {hitung }}$ sebesar 2,841 lebih besar daripada $t_{\text {tabel }}$ yang bernilai 2,021 pada taraf signifikan $5 \%$ dengan $\mathrm{db}=$ 40, sehingga $\mathrm{H}_{0}$ ditolak dan $\mathrm{H}_{\mathrm{a}}$ diterima. Hal ini menunjukkan bahwa terdapat pengaruh model pembelajaran koopetatif tipe STAD dan Jigsaw terhadap penguasaan konsep fisika.

Model pembelajaran kooperatif tipe STAD dan Jigsaw sama-sama berpengaruh karena tipe STAD dan Jigsaw memiliki ciri yang sama yaitu pemberian penghargaan (reward) kepada peserta didik yang mengalami peningkatan yang diberikan tidak terbatas pada fase, namun dapat diberikan selama proses pembelajaran berlangsung, kapanpun guru merasa peserta didik berhak mendapatkan penghargaan atas usaha yang telah dilakukan peserta didik dalam berkontribusi pada saat kegiatan belajar mengajar.Pendapat ini didukung oleh Isjoni (2011), bahwa pengembang model ini telah menunjukkan bahwa model struktur 
penghargaan kooperatif telah dapat meningkatkan penilaian siswa pada belajar akademik dan perubahan norma yang berhubungan dengan hasil belajar dan unggul dalam membantu siswa memahami konsepkonsep yang sulit.

Model pembelajaran kooperatif tipe STAD dan Jigsaw memiliki pengaruh terhadap penguasaan konsep peserta didik, namun kedua model menghasilkan nilai ratarata yang berbeda. Terlihat pada tabel 1 data penguasaan konsep peserta didik bahwa ratarata nilai kelas eskperimen 1 yang diberi perlakuan berupa model pembelajaran kooperatif tipe STAD memiliki nilai rata-rata yang lebih tinggi dibanding kelas eksperimen 2 yang diberi pelakuan berupa model pembelajaran kooperatif tipe Jigsaw. Siswa yang diberi pelakuan berupa model pembelajaran kooperatif tipe STAD dan Jigsaw memiliki nilai rata-rata berturut-turut 73,69 dan 61,07. Hal ini disebabkan karena terdapat perbedaan yang mendasar dalam salah satu sintaks pembelajaran, dimana pada model pembelajaran kooperatif tipe STAD, guru masih menyajikan materi dan membimbing peserta didik untuk menguasai materi pembelajaran yang kemudian dalam diskusi kelompok peserta didik yang pintar dapat menjelaskan kepada anggota kelompoknya yang belum paham. Pada model pembelajaran kooperatif tipe Jigsaw siswa dituntut untuk menjadi ahli dalam satu pokok bahasan sehingga setiap peserta didik memiliki tanggung jawab yang berbeda dengan anggota kelompok yang lain, hal ini menyebabkan peserta didik hanya terfokus mempelajari materi sesuai bidang keahliannya, selain itu, menurut peneliti peserta didik di kelas XI SMAN 1 Kediri belum dapat bertanggung jawab sepenuhnya terhadap persoalan yang diberikan. Peserta didik masih memerlukan bimbingan dari guru untuk menguasai materi pelajaran. Menurut Sari (2010), prinsip dasar dari tipe Jigsaw adalah sikap ketergantungan positif antar individu. Tipe jigsaw diibaratkan sebagai Jigsaw puzzle yang tidak akan lengkap tanpa tiap kepingan saat digabungkan. Hal ini terjadi karena tipe ini melibatkan partisipasi aktif dari setiap individu dalam kerja kelompok dan mareri pelajaran disusun sedemikian rupa sehingga setiap anggota kelompok memiliki informasi dan pengaruh tersendiri terhadap kelompoknya. Hal inilah yang menjadi kekurangan bagi tipe Jigsaw untuk di terapkan di SMAN 1 Kediri, karena peserta didik tidak semua dapat menggabungkan kepingan-kepingan materi untuk digabungkan, sehingga menghambat peserta didik yang lain untuk memahami materi.

Hasil penelitian ini didukung oleh Rasim (2010) yang menyatakan bahwa antara model pembelajaran kooperatif tipe STAD dan Jigsaw memiliki perbedaan pengaruh terhadap prestasi belajar peserta didik. Tipe STAD lebih baik daripada Jigsaw untuk pembelajaran fisika, namun kedua tipe ini sama-sama dapat digunakan dalm pembelajaran fisika karena menunjukkan hasil yang memuaskan yaitu kelas yang diberi perlakuan baik tipe STAD maupun Jigsaw memenuhi KKM. Hal ini disebabkan kerjasama yang dilakukan siswa dalam kelompok pembelajaran kooperatif tipe STAD lebih baik dibandingkan dengan kerjasama dalam pembelajaran kooperatif tipe Jigsaw. Hal ini sesuai juga dengan penelitian yang dilakukan oleh Doyan (2015) yang menyatakan bahwa ada perbedaan pengaruh model pembelajaran kooperatif tipe STAD dan tipe Jigsaw terhadap hasil belajar fisika. Peserta didik yang diajar menggunakan model pembelajaran kooperatif tipe STAD memberikan hasil belajar yang lebih tinggi dibanding dengan siswa yang diajar menggunakan model pembelajaran kooperatif tipe Jigsaw dengan selisih rerata yang dihasilkan kedua model pembelajaran tersebut memiliki rentang yang cukup jauh. Hal ini disebabkan karena pada sekolah tempat penelitian dilakukan model pembelajaran kooperatif tipe Jigsaw asing bagi peserta didik, sehingga guru harus sering menjelaskan tentang aturan-aturan jigsaw pada saat kegiatan belajar mengajar yang mengakibatkan kurang optimalnya waktu pertemuan pembelajaran digunakan untuk berdiskusi.

Meta-analisis model pembelajaran kooepratif yang dilakukan oleh David W dan 
kawan-kawannya dalam penelitian Cooperative Learning Methods: A Meta Analysis juga menemukan bahwa STAD selalu lebih baik rankingnya daripada Jigsaw, baik dalam hal rasio antara sifat kooperatif dengan kompetisi $(\mathrm{STAD}=0,51$; Jigsaw $=0,29$ ) dan rasio antara sifat kooperatif dengan individu (STAD=0,29; Jigsaw=0,13). Metaanalisis tersebut menunjukkan hasil bahwa pembelajaran dengan model pembelajaran kooperatif tipe STAD akan lebih baik hasilnya daripada model pembelajaran kooperatif tipe Jigsaw.

Berdasarkan hasil kedua penelitian dan meta-analisis diatas, apa yang ditemukan pada penelitian ini telah sesuai, yaitu hasil kedua kelas yang dibelajarkan dengan tipe STAD dan Jigsaw memiliki pengaruh terhadap penguasaan konsep peserta didik. Kendalakendala yang dialami oleh peneliti khususnya saat melaksanakan pembelajaran di sekolah ialah kurang optimalnya dalam pembimbingan diskusi peserta didik dan pengelolaan waktu. Pada pembelajaran kooperatif diperlukan banyak waktu terutama untuk tipe Jigsaw dimana diskusi dalam kelompok asal dan kelompok ahli. Pelaksanaan quiz di akhir pembelajaran tidak dapat dilakukan karena kurangnya waktu. Kendala lainnya yaitu tidak terbiasanya peserta didik diberikan tanggung jawab berupa materi untuk diajarkan kepada teman sebayanya. Peserta didik di SMAN 1 Kediri masih harus selalu dibimbing setiap mengalami kesulitan, sehingga belum tepat untuk diberikan perlakuan tipe Jigsaw yang memberikan tanggung jawab yang besar pada peserta didik dalam menguasai materi. Pada saat pembentukan kelompok, tidak semua peserta didik bersedia dikelompokkan berdasarkan ketentuan model pembelajaran kooperatif. Hubungan sosial yang renggang antara siswa yang berkemampuan tinggi dengan siswa yang berkemampuan rendah menyebabkan beberapa siswa tidak berkenan jika mereka dikelompokkan dalam satu tim yang sama, sehingga dalam proses pembelajaran kadang peserta didik sering menyampaikan keluhannya terhadap teman kelompoknya kepada guru karena menghambat teman-temannya saat berdiskusi.
Terlepas dari segala kekurangan dalam penelitian ini, peneliti membuktikan bahwa model pembelajaran kooperatif tipe STAD dan Jigsaw berpengaruh terhadap penguasaan konsep fisika peserta didik kelas XI SMAN 1 Kediri, berdasarkan hasil uji hipotesis yang telah dilakukan, model pembelajaran kooperatif tipe STAD dan Jigsaw dapat dijadikan alternatif untuk meningkatkan penguasaan konsep peserta didik.

\section{KESIMPULAN}

Berdasarkan hasil penelitian dan pembahasan dapat disimpulkan bahwa terdapat pengaruh model pembelajaran kooperatif tipe STAD dan Jigsaw terhadap penguasaan konsep fisika.

\section{SARAN}

Pembelajaran kooperatif tipe Jigsaw memerlukan waktu yang banyak dalam implementasinya, sehingga sebaiknya perlu disiapkan perencanaan dan pembagian waktunya sebaik mungkin, agar tujuan pembelajaran dan kegiatan di tiap fase dapat terlaksana secara maksimaldan penelitian dengan menggunakan model pembelajaran kooperatif tipe STAD dan Jigsaw seyogyanya dapat dilanjutkan dengan mengaitkan variabel-variabel yang belum diungkap agar lebih bermanfaat dalam dunia pendidikan.

\section{DAFTAR PUSTAKA}

Anderson, L.W., Krathwohl, D. R (2015). Pembelajaran, Pengajaran, dan Asesmen. Yogyakarta: Pustaka Pelajar.

Buchari, A. 2008. Guru Profesional Menguasai Metode dan Trampil Mengajar). Bandung: Alfabeta

David, W. J., Johnson, R. T., dan Stanne, M. B. Cooperative Learning Methods: A Meta-Analysis. (2000). University of Minnesota: Minnesota.

Doyan, A., Gunada, W., Susilawati, \& Ayu D.A.A. (2015). Perbedaan Pengaruh Model Pembelajaran Kooperatif Tipe STAD dan Tipe Jigsaw Terhadap Hasil Belajar Fisika Ditinjau dari Motivasi Belajar Siswa. Jurnal Penelitian Pendidikan IPA (JPPIPA).

Hakim, S., Wahyudi, dan Verawati, N. N. S. P. (2018).Pengaruh Model Pembelajaran Contextual Teaching And Learning (Ctl) Berbantuan Lks 
Jurnal dan Pendidikan Ilmu Sosial

http://ejournal.mandalanursa.org/index.php/JISIP/index

Terhadap Hasil Belajar Fisika Siswa Sma Attohiriyah Bodak. Jurnal Kpendidikan Fisika "Lensa"Vol. 6 No.1, ISSN 2338-4417. IKIP Mataram.

Hikmawati. (2014). Strategi Pembelajaran Fisika. Mataram: Fkip Press Unram.

Isjoni. (2011). Cooperative Learning. Bandung: Alfabeta.

Islamiah, A. F., Rahayu, S., dan Verawati, N. N. S. P. (2018). Efektivitas Model Pembelajaran Problem Based Learning Berbantuan Lks Terhadap Kemampuan Berpikir Kritis Fisika Siswa Sman 1 Lingsar Tahun Ajaran 2016/2017. Jurnal Kpendidikan Fisika "Lensa"Vol. 6 No.1, ISSN 2338-4417. IKIP Mataram.

Kemendikbud. (2014). Modul Pelatihan Implementasi Kurikulum 2013. Jakarta: Kementerian Pendidikan dan Kebudayaan RI.

Larasati, A., Yulianti D. (2014). Pengembangan Bahan Ajar Sains (Fisika) Tema Alam Semesta Terintegrasi Karakter dan Berwawasan Konservasi. Unnes Physics Education Journal 3(2) ISSN.2252-6935: UNS.

Nyoman, I S., Harjono, A., dan Sahidu, C. (2016). Pengaruh Model Pembelajaran Generatif Berbantuan Media Laboratorium Virtual Terhadap Penguasaan Konsep Fisika Siswa pada Materi Momentum dan Impuls. Jurnal Pendidikan Fisika dan Teknologi Volume II No. 2. Universitas Mataram.

Rahayu, S. (2015). Model Simulasi dalam Mata Kuliah Strategi Pembelajaran Fisika. Jurnal Pendidikan Fisika dan Teknologi (ISSN. 2407-6902) Volume I No. 2. Universitas Mataram.

Latifa, B. R. A., Verawati, N. N. S. P., dan Harjono, A. (2017). Pengaruh Model Learning Cycle 5e (Engage, Explore, Explain, Elaboration, \& Evaluate) Terhadap Kemampuan Berpikir Kritis Peserta Didik Kelas X Man 1 Mataram. Jurnal Pendidikan Fisika dan Teknologi (ISSN. 2407-6902) Volume III No. 1. Universitas Mataram

Sari, I. J. (2010). Pembelajaran Kooperatif Tipe Jigsaw Ditinjau dari Kecerdasan
Vol. 4. No. 1 Januari 2020

p-ISSN: 2598-9944 e-ISSN: 2656-6753

Emosional dan Spiritual Siswa SMP. Skripsi. Fakultas Keguruan dan Ilmu Pendidikan Universitas Sebelas Maret. Surakarta.

Verawati, N., N., S., P., Kosim., Gunawan., 'Ardhuha, J., \& Arizona, K. (2017). Pengembangan Bahan Ajar Fisika Berbasis LKM Ceria untuk Meningkatkan Keterampilan Berpikir Kritis dan Kreatif Mahasiswa Calon Guru Fisika. Lensa : Jurnal Kependidikan Fisika, 5(1), 18-22. Retrieved from http://ojs.ikipmataram.ac.id/index.php/L ensa/article/view/129 